\title{
HAK-HAK ANAK DAN IDEOLOGI ORANG DEWASA: KAJIAN MITOS ROLAND BARTHES DALAM NOVEL GRAFIS MESIR SALMA TA'RIFU HUQUUQAHAA
}

\author{
REZA SUKMA NUGRAHA* \\ reza.sn@staff.uns.ac.id \\ AFNAN ARUMMI* \\ afnanarummy85@staff.uns.ac.id \\ TRI YANTI NURUL HIDAYATI* \\ nurulhidayati t@staff.uns.ac.id
}

*Program Studi Sastra Arab, Fakultas Ilmu Budaya, Universitas Sebelas Maret, Indonesia

\begin{abstract}
ABSTRAK
Sebagai bacaan anak, novel grafis Salma Ta'rifu Huquuqahaa (STH) karangan Fathimah al-Ma'dul menunjukkan karakteristik yang relevan dengan sastra anak. Selain ditampilkan dengan ilustrasi yang dapat menarik perhatian pembaca anak, narasinya pun menunjukkan unsur didaktik yang jelas, yaitu kesadaran akan hak-hak anak dan kepedulian terhadap lingkungan sosial. Moral tersebut ditampilkan melalui karakter anak bernama Salma. Akan tetapi, permasalahan muncul dalam karakterisasi Salma yang menjadi tokoh utama sekaligus penyampai moral. Selain itu, representasi moral di dalamnya perlu dibaca secara kritis agar maknanya dapat ditangkap oleh pembaca, baik pembaca anak-anak maupun pembaca umum. Oleh karena itu, dilakukan penelitian kualitatif dengan menggunakan teori Semiotika Roland Barthes sebagai pendekatan. Dengan melakukan pembacaan bertahap (signifikansi) terhadap tanda-tanda yang ada di dalam teks, diperoleh hasil bahwa teks STH menampilkan moral terkait kesadaran akan hak-hak anak dalam rangka melakukan sosialisasi Konvensi Hak-hak Anak PBB sebagai pedoman hak-hak anak secara global. Selain itu, mitos yang diungkapkan melalui sosialisasi itu adalah kampanye terhadap hak-hak anak di Mesir yang digagas oleh Suzanne Mubarak pada saat teks diterbitkan (2016).
\end{abstract}

Kata kunci: Ideologi, Novel Grafis, Roland Barthes, Sastra Anak, Semiotika

\section{ABSTRACT}

As a reading book, the graphical novel of Salma Ta'rifu Huquuqahaa (STH) by Fatimah al-Ma'dul shows relevant characteristics with children's literature. Beside presented by an illustration attracting child readers, its narration indicates the clear didactical elements, in terms of the awareness of the rights of the child and concern on the social environment. These morals are reflected through a child character namely Salma. However, the problem reflects in the characterization of Salma as the main character as well as a moral conveyor. Besides, the representation of these morals requires a critical reading so that readers in terms of children, adolescents, and adults, can understand the meaning. Hence, a qualitative study was conducted using a Semiotic approach proposed by Roland Barthes. By reading (significance) one sign after another in the text, the study indicates that the STH text represents morals concerning the awareness toward the rights of the child to socialize Convention of the Rights of the Child by United Nation as a guideline of the rights of the child globally. Moreover, the myth portrayed through this socialization is a campaign on the rights of the child in Egypt proposed by Suzzane Mubarak when the text was published (2016).

Keywords: Ideology, Graphical Novel, Roland Barthes, Children's Literature, Semiotics 


\section{PENDAHULUAN}

Sastra anak adalah genre sastra yang mencakup berbagai jenis bacaan yang ditujukan untuk pembaca anak. Dalam beberapa definisi yang dikemukakan ahli, tidak ada batasan khusus mengenai usia penulis sastra anak. Namun demikian, sebagian definisi menyebutkan bahwa sastra anak ditulis oleh orang dewasa dengan memperhatikan dunia anak sebagai pembaca yang dibidiknya. Oleh karena itu, beberapa karya sastra anak ditulis oleh dewasa dengan tetap berpegang teguh pada karakteristik sastra anak, yaitu relevan dengan dunia anak dan mengandung nilai didaktif dalam penceritaannya (Hunt, 2002; Kurniawan, 2009; Nurgiyantoro, 2005).

Di antara genre sastra anak tersebut, novel grafis adalah salah satu bentuk sastra anak yang ditemukan dalam berbagai kesusastraan. Novel grafis adalah tulisan naratif khas prosa yang dilengkapi dengan gambar atau ilustrasi (Beatens, 2001). Gambar tersebut berfungsi mendukung cerita yang disajikan. Namun demikian, novel grafis berbeda dengan komik yang cenderung berfokus pada sajian gambar sebagai aspek utama. Dalam kaitannya dengan sastra anak, novel grafis banyak diproduksi untuk pembaca anak karena gambar dalam narasi yang disajikannya adalah salah satu elemen yang bisa menarik minat pembaca anak.

Dalam kesusastraan Arab mutakhir, novel grafis ditulis oleh penulis-penulis tertentu, khususnya penulis sastra anak. Di antaranya adalah Fatimah al-Ma'dul, penulis sastra anak asal Mesir. Al-Ma'dul (lahir 1948) termasuk penulis Mesir yang produktif menulis bacaan anak (Ashour, 2008, hal. 434). Di antara karyanya yang ditulis pada era 2000-an adalah novel grafis Salma Ta'rifu Huquuqahaa (Salma Tahu
Hak-Haknya, selanjutnya disingkat STH). Novel yang diterbitkan Penerbit Nahdhat Mishr pada 2006 tersebut bercerita mengenai perjuangan seorang anak bernama Salma yang berusaha mendirikan perpustakaan di kampungnya yang terpencil di Gurun Timur.

Salma diceritakan sebagai anak kecil yang tinggal bersama saudarasaudaranya, Ali dan Khadijah. Ali memiliki hobi bermain bola, sedangkan Khadijah senang merajut. Adapun Salma gemar membaca buku, tetapi dia tidak memiliki banyak buku. Di kampungnya pun tidak ada perpustakaan sehingga tidak ada kesempatan bagi Salma untuk dapat membaca buku. Didorong oleh keinginannya untuk memiliki perpustakaan di kampungnya, Salma berinisiatif untuk mengirimkan surat kepada pemerintah. Lewat suratnya, Salma menyatakan bahwa dia ingin kampungnya memiliki perpustakaan sehingga anak-anak sepertinya dapat membaca banyak buku.

Di dalam cerita tersebut, Salma dikarakterisasi sebagai anak kecil yang memiliki inisiatif baik. Hal tersebut tidak hanya bermanfaat bagi dirinya, melainkan untuk anak-anak di kampungnya. Dengan demikian, Salma tampil sebagai anak yang memiliki kepedulian tinggi terhadap lingkungannya. Sebagai anak, upayaupaya ditampilkan Salma memiliki nilai moral yang baik untuk ditiru. Hal tersebut sejalan dengan tujuan sastra anak yang mementingkan nilai didaktif di dalamnya. Oleh karena itu, pada tahap ini teks STH layak dikategorikan sebagai sastra anak.

Namun demikian, ada beberapa masalah yang menarik untuk dikaji dalam teks tersebut. Pertama, karakter Salma sebagai anak yang ideal karena memiliki inisiatif besar untuk mengubah 
lingkungannya. Sebagai tokoh anak kecil, tentu ada beberapa hal yang perlu dikritisi terkait pembentukan karakter tersebut dan realisasinya dalam kehidupan nyata. Kedua, moral yang disajikan terkait inisiatif tersebut harus dilihat dari kacamata "orang dewasa" karena teks tersebut ditulis oleh AlMa'dul sebagai penulis dewasa yang bisa saja menyisipkan berbagai ideologi dewasanya ke dalam teks.

Setiap bacaan tidak pernah kosong dari ideologi. Menurut McCallum dan Stephens (2011), setiap bacaan, termasuk untuk anak-anak, selalu memiliki implikasi ideologis kepada pembacanya. Implikasi itu bisa muncul dalam setiap bahasa atau gambar yang digunakan dalam bacaan tersebut. Dengan demikian, setiap perangkat naratif yang ada dalam teks berpotensi untuk menunjukkan suatu gagasan implisit bernama ideologi untuk disampaikan kepada pembaca.

Beberapa penelitian telah dilakukan untuk menganalisis ideologi dalam bacaan anak. Nursugiharti (2020) dalam analisisnya terkait ideologi dalam buku Sang Pendekar Bumi Melayu menyebutkan adanya ideologi politeis, monoteis, dan nasionalis di dalamnya. Jenis-jenis ideologi itu dikaji melalui struktur teks yang berkaitan satu sama lain. Representasi ideologi tersebut ditampilkan sesuai perkembangan usia dan peran tokoh di dalam teks. Nursugiharti melihat bahwa ideologi di dalam teks tidak selalu selaras dengan usia anak. Dengan demikian, diperlukan bimbingan orang dewasa ketika anak membaca teks tersebut sehingga ideologi yang dimaksud dipahami secara keliru.

Sejalan dengan penelitian tersebut, tulisan ini mengkaji kemungkinan munculnya ideologi orang dewasa dalam teks STH. Penelusuran terhadap ideologi tersebut dilakukan dengan pembacaan semiotika Roland Barthes atas tandatanda yang ada di dalam teks, meliputi narasi dan ilustrasi yang mendukung. Tanda-tanda tersebut terkait dengan karakterisasi tokoh dan berbagai kemungkinan ideologi dewasa yang muncul dalam narasi dan ilustrasi yang disajikan.

Konsep dasar Semiotika Barthes bermula dari teori dikotomi tanda yang digagas Ferdinand de Saussure. Teori dikotomi Saussure membagi pemaknaan tanda atas dua hubungan, yaitu signifier (penanda) dan signified (petanda). Signifier adalah tanda yang tampil dalam realitas yang terinderakan, seperti katakata, kalimat, paragraf, hingga ilustrasi yang terdapat dalam novel grafis. Adapun signified adalah konsep kognitif yang diacu oleh signifier. Dalam konteks novel grafis, beragam kata, kalimat, paragraf, dan iustrasi menunjukkan sebuah proses mental yang diproduksi dalam kognisi. Proses mental itu adalah pembacaan atas tanda-tanda yang tampil sebagai signifier.

Berangkat dari teori Saussure, Barthes mengembangkan konsep dikotomi Saussure menjadi pembacaan berlapis atas tanda-tanda tersebut. Pembacaan berlapis tersebut adalah dengan mengembangkan hubungan signifier dan signified (yang disebut sebagai sign/tanda) menjadi signifier 2. Barthes menyebut signifier dengan expression dan signified dengan content (Barthes, 1972). Sebagai suatu signifier, maka signifier 2 ini secara otomatis merujuk pada signified 2 pula. Setelah itu, hubungan antara signifier 2 dan signified 2 (yang disebut dengan sign 2 berpotensi menjadi signifier 3. Begitu seterusnya hingga pembacaan atas tanda-tanda tersebut tidak pernah berakhir. Makna yang timbul dari pembacaan signifier 2-signified 2 dan seterusnya disebut Barthes sebagai mitos atau makna kononatif. Bagan yang 
paling banyak digunakan untuk memahami konsep ini adalah sebagai berikut: berkaitan dengan hak-hak anak. Langkah penelitian mencakup: (1) pembacaan menyeluruh terhadap teks STH, (2)

\begin{tabular}{|c|c|c|c|c|}
\hline \multirow{3}{*}{$\begin{array}{c}\text { Language/ } \\
\text { Dennotative }\end{array}$} & 1. Signifier & 2. Signified & & \multirow{3}{*}{$\begin{array}{l}\text { Myth/ } \\
\text { Connotative }\end{array}$} \\
\hline & I. S & $\begin{array}{l}\text { nn } \\
\text { ifier }\end{array}$ & II. Signified & \\
\hline & \multicolumn{3}{|c|}{ III. Sign } & \\
\hline
\end{tabular}

Bagan 1 Semiotika Roland Barthes

Mitos inilah yang digunakan untuk membongkar makna-makna implisit yang muncul dalam teks STH. Mitos tersebut akan dikaitkan dengan dua masalah, yaitu karakterisasi tokoh Salma sebagai anak-anak dan ideologi dewasa yang tersembunyi di balik nilai moral yang disajikan dalam teks tersebut. Dengan demikian, akan diperoleh makna konotatif di balik narasi mengenai Salma sebagai tokoh anak yang berjuang untuk kepentingan lingkungannya.

\section{METODE}

Penelitian ini menggunakan metode kualitatif dengan teknik analisis isi. Teknik tersebut menggunakan analisis teks yang sistemik, termasuk gambar, ilustrasi, dan simbol-simbol yang muncul di dalam teks. Semua materi tersebut berguna untuk menciptakan inferensi yang valid (Krippendorf, 2004; Weber, 1990). Dengan demikian, dalam penelitian ini, data-data akan mencakup narasi dan ilustrasi pada teks untuk dianalisis dengan pendekatan Semiotika Roland Barthes sebagaimana telah disebutkan sebelumnya.

Sumber data penelitian ini adalah novel grafis Salma Ta'rifu Huquuqahaa karangan Fathimah al-Ma'dul, pengarang bacaan anak dari Mesir. Novel grafis tersebut diterbitkan pada 2016 oleh Penerbit Nahdhat Mishr. Adapun datadata di dalamnya yang digunakan adalah narasi dan ilustrasi terkait upaya tokoh utama Salma menampilkan moral yang pencarian data terkait, (2) analisis data dengan metode dan pendekatan yang telah ditentukan, (3) penarikan simpulan.

\section{HASIL DAN PEMBAHASAN}

Sebagaimana telah disebutkan semiotika Barthes digunakan untuk menganalisis karakter tokoh Salma dan ideologi di balik nilai moral yang disajikan dalam teks. Dalam teks terdapat beberapa tokoh yang disebutkan, yaitu Salma sebagai tokoh utama, lalu Ali dan Khadijah sebagai saudara Salma, dan Ustadzah Asma sebagai perwakilan pemerintah. Di dalam teks juga disebutkan nama Mama Suzanne sebagai orang yang dituju oleh Salma saat menulis surat.

\section{Karakter Salma sebagai Anak}

Di dalam teks, tidak terdapat narasi yang eksplisit menunjukkan usia Salma. Namun, di dalam teks Salma disebut sebagai thiflatun (طفلة) yang berarti anakanak. Dalam beberapa penceritaan lain, kata thiflun (طفل) dan athfaal (أطفال) disebut beberapa kali. Dalam bahasa Arab, kata tersebut, secara leksikal bermakna anak-anak sejak dilahirkan hingga mencapai usia baligh, yaitu fase perkembangan anak menuju dewasa (Mu'jam Al-Ma'ani).

Berikut beberapa kutipan yang menunjukkan pemakaian kata tersebut. 
Kutipan 1:

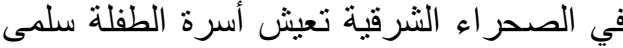

و أختها خديجة وأخو ها علي (المعدول، 2006:2).

Arti:

Di Gurun Timur, hidup keluarga seorang kecil bernama Salma dan saudaranya, Khadijah dan Ali (Al-Ma'dul, 2006:2).

\section{Kutipan 2:}

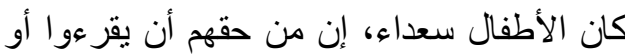

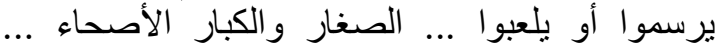

$$
\begin{aligned}
& \text { و المختلفون ... (المعدول، 2006:15). }
\end{aligned}
$$

Arti:

Anak-anak gembira. Hak-hak mereka untuk dapat membaca, menggambar, atau bermain. Kecil besar, yang sehat maupun difabel .... (Al-Ma'dul, 2006, hal. 15).

Selain itu, ilustrasi yang ditampilkan mengenai Salma dan tokohtokoh lainnya menunjukkan bahwa karakter dalam teks tersebut adalah anak-anak. Terdapat pula penggambaran karakter fisik Salma yang lebih kecil dari kakaknya, Khadijah. Hal tersebut menegaskan bahwa tokoh Salma adalah anak-anak, sejalan dengan genre teks tersebut sebagai sastra anak.

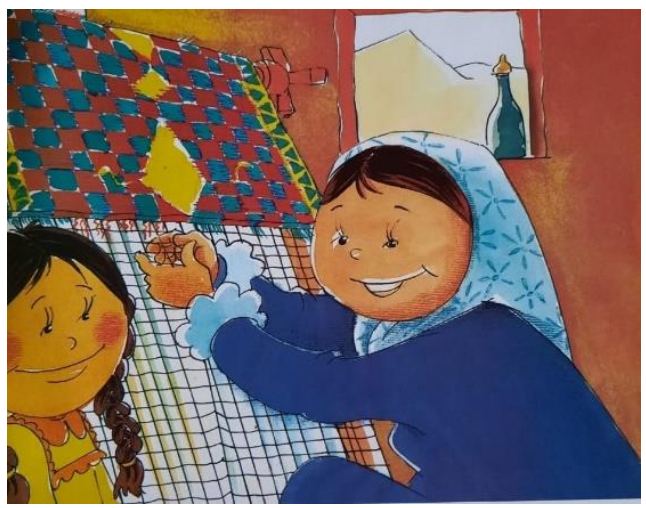

Gambar 1. Salma dan Kakaknya, Khadijah

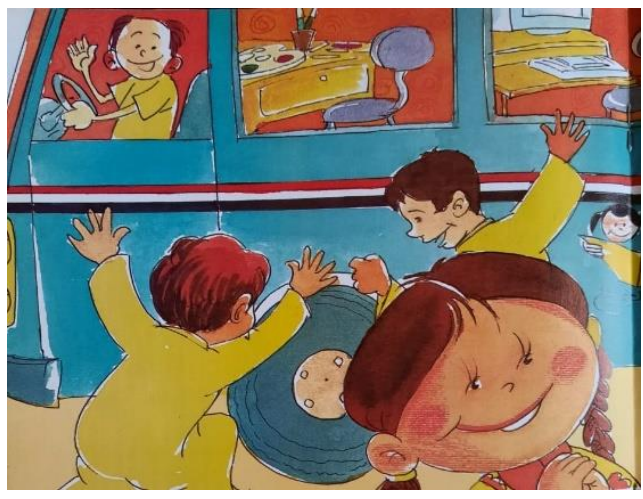

Gambar 2. Salma dan Teman-temannya.

Dalam gambar 1, tampak penggambaran fisik Salma berbeda dari kakaknya. Salma tampak lebih kecil sehingga terlihat bahwa Salma adalah "adik" dari Khadijah. Hal tersebut karena dalam bahasa Arab, kata yang digunakan adalah ukhtun (أخت) 'saudara' yang tidak membedakan antara adik dan kakak. Dengan demikian, ilustrasi membantu menunjukkan karakter fisik Salma sebagai anak-anak dalam teks tersebut.

Adapun dalam gambar 2, terlihat Salma dan teman-temannya bergembira atas kedatangan mobil perpustakaan dari kota. Karakter fisik Salma dan teman-teman tergambar sebagai anakanak dalam gambar tersebut dengan dikontraskan dengan tokoh sopir mobil. Karakter anak-anak yang gembira juga didukung oleh gambar tersebut, karena Salma dan salah satu temannya menunjukkan bibir tersenyum dan terbuka lebar.

Dalam pembacaan Semiotika Barthes, makna di balik penggunaan kata thiflun serta gambar 1 dan gambar 2 sebagaimana dijelaskan sebelumnya adalah bagian dari pembacaan atas tanda-tanda tersebut sebagai signifier 1 . Artinya, penjelasan tersebut merupakan makna denotatif yang diperoleh dari kemunculan tanda tersebut dalam teks. Makna leksikal dari kata thiflun dan pembacaan atas gambar karakter Salma 
dan teman-temannya adalah signifikansi tahap pertama dalam Semiotika Barthes.

Kemudian, pemaknaan tersebut berlanjut pada signifikasin tahap kedua, yaitu menghubungkan antara pemaknaan yang telah diperoleh tersebut dengan sebuah konsep mitos yang berada di balik tanda-tanda tersebut. Penggunaan kata thiflun pada tokoh utama Salma, didukung oleh ilustrasi yang dicontohkan pada gambar 1 dan gambar 2 menunjukkan bahwa teks tersebut mempertegas fungsinya sebagai bacaan anak. Hal tersebut menjadi penting sebelum menelisik moralitas dan ideologi yang secara implisit dikehendaki pengarang.

Teks STH telah memenuhi persyaratan sebagai bacaan anak dengan menjadikan tokoh anak dan dunianya sebagai pusat penceritaan. Selain itu, ilustrasi yang diberikan mendukung hal tersebut, mengingat sastra anak harus dengan jeli memperhatikan kemasannya karena membidik anak-anak sebagai pembaca. Penggunaan gambar karikatural seperti yang ditampilkan gambar 1 dan gambar 2 adalah upaya pengarang dan penerbit memberikan kemasan buku yang menarik untuk anak.

Jika digambarkan dalam bagan Semiotika Barthes, pemaknaan tersebut akan tampak seperti berikut:

Bagan 2. Makna Denotatif dan Konotatif STH

\begin{tabular}{|c|c|c|}
\hline Gambar 1 & $\begin{array}{c}\text { Penggambaran } \\
\text { fisik anak-anak, } \\
\text { kontras dengan } \\
\text { kakaknya yang } \\
\text { lebih besar }\end{array}$ & \multirow[t]{3}{*}{ Gambar 3. Surat Salm } \\
\hline Signifier & Signified & \\
\hline \multicolumn{2}{|c|}{ Denotative Sign } & \\
\hline \multicolumn{2}{|c|}{ Konsep anak-anak pada gambar } & $\begin{array}{c}\text { Penegasan teks STH atas fungsinya } \\
\text { sebagai bacaan anak }\end{array}$ \\
\hline \multicolumn{2}{|c|}{ Signifier 2} & Signified 2 \\
\hline
\end{tabular}


Dalam gambar 3 tampak Salma menulis surat yang berisi sebagai berikut, "Saya Salma. Saya tinggal di Gurun Timur. Saya senang membaca dan saya ingin kampung kecil kami memiliki perpustakaan." Surat tersebut ditujukan kepada pemerintah setempat dengan Mama Suzanne (Al-Ma'dul, 2006:6-7). Tidak ada penjelasan mengenai Mama Suzanne di dalam teks, tetapi nama yang disebut tersebut merujuk pada tokoh Suzanne Mubarak, istri Presiden Mesir era 1981-2011.

Tidak berselang lama, upaya Salma berhasil. Kampung Salma kedatangan mobil perpustakaan yang besar. Perpustakaan bergerak tersebut memiliki koleksi buku yang lengkap, fasilitas anak-anak seperti untuk mewarnai, menonton film, dan mendengarkan musik, serta komputer. Penanggung jawab perpustakaan tersebut, Ustadzah Asma, kemudian berterima kasih kepada Salma atas jasanya sehingga anak-anak di kampungnya dapat merasakan manfaat perpustakaan tersebut. Bahkan, anakanak di fabel pun bisa merasakan manfaat yang sama.

Secara eksplisit, ucapan terima kasih Ustadzah Asma terlihat dalam beberapa kutipan berikut.

Kutipan 3:

ظهرت من العربة الكبيرة الأستاذة أسماء، وقالت

للأو لاد و البنات: اشكروت صند صديقتكم سلمى ... فإنها طفلة

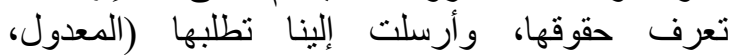

.2006:10

Arti:

Dari mobil van besar itu, tampak Ustadzah Asma. Ia berkata kepada anakanak, "Kalian harus berterima kasih kepada teman kalian, Asma. Asma adalah anak yang mengerti hak-haknya, dan dia mengirim dan memintanya kepada kami" (Al-Ma'dul, 2006, hal. 10).
Kutipan 4:

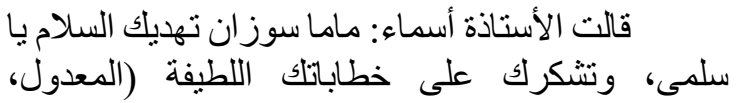

.2006:12

Arti:

Ustadzah Asma berkata, "Mama Suzanne mengirimkan salam kepadamu, Salma. Beliau mengucapkan terima kasih atas suratmu yang baik" (Al-Ma'dul, 2006:12).

Kutipan 5:

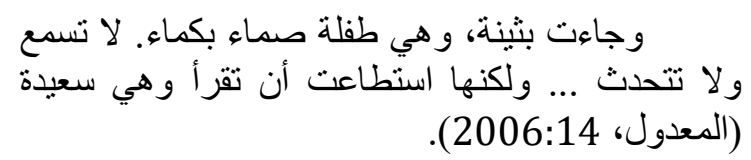

Arti:

Butsainah datang. Dia adalah seorang anak yang tuli dan bisu. Dia tidak bisa mendengar dan bicara. Namun, dia bisa membaca dan dia senang (AlMa'dul, 2006:14).

Melalui kutipan tersebut, Salma tampak sebagai pahlawan bagi anakanak lainnya. Dia disebut Ustazah Asma "paham hak-hak anak" sehingga temantemannya patut berterima kasih kepadanya. Bahkan, Mama Suzanne mengucapkan rasa terima kasih yang sama. Sebagai tokoh utama, Salma ditampilkan sebagai pembawa moral bagi keseluruhan teks STH terkait perjuangannya menghadirkan perpustakaan di kampungnya.

Moral utama yang dihadirkan teks adalah perlunya kesadaran dalam diri anak-anak, sebagaimana direpresentasikan oleh Salma. Secara spesifik, hak-hak yang dimaksud adalah hak mendapatkan pendidikan dan hiburan. Selain itu, hak memperoleh kesetaraan dalam perlakuan juga menjadi pesan yang ditampilkan melalui hadirnya tokoh anak difabel. Hak-hal 
tersebut diperjuangkan Salma, seorang anak kecil yang hidup di sebuah desa terpencil.

Dalam teori perkembangan moral Kohlberg, disebutkan bahwa perkembangan moral dibagi menjadi tiga tahap penting, yaitu prakonvensional, konvesional, dan pascakonvesional. Ketiga tahapan itu dibagi kembali menjadi dua tahap sehingga terdapat enam tahap secara berurutan sesuai orientasinya: (1) orientasi pada hukuman dan kepatuhan, (2) orientasi instrumental, (3) orientasi "anak baik", (4) orientasi hukum dan tatanan, (5) orientasi kontrak sosial, dan (6) orientasi universal-etis-asasi (Garz, 2009).

Setiap tahap memiliki karakteristik yang berbeda sesuai dengan kelompok usianya. Kohlberg menyebutkan bahwa tahap prakonvensional yang ciri utamanya adalah kepatuhan pada aturan tanpa bertanya serta kepatuhan atas dasar hadiah dan hukuman biasanya terjadi pada anak-anak hingga usia sembilan tahun. Berbeda dengan tahap konvensional yang terjadi pada anakanak mulai sembilan tahun hingga remaja awal dengan karakteristik menjadi baik atas dasar mayoritas sosial dan munculnya tanggung jawab kepada lingkungan sosial. Kemudian, tahap terakhir, yaitu pascakonvensional biasanya terjadi pada usia dewasa dengan karakteristik bahwa moral ditentukan oleh nilai dan kesadaran pribadi.

Mengacu pada teori Kohberlg tersebut, kesadaran yang muncul dalam diri Salma sebagai seorang anak menunjukkan sikap moral yang biasa terjadi pada tahap konvensional yang kedua, yaitu moral yang berorientasi pada hukum dan tatanan. Artinya, kesadaran Salma untuk memperjuangkan hak-haknya dalam menghadirkan perpustakaan adalah bentuk tanggung jawabnya terhadap lingkungan sosialnya. Ada upaya untuk mewujudkan sebuah kebaikan kepada orang-orang di sekitar dengan dasar bahwa kebaikan itu adalah suatu keharusan sosial atau bagian dari norma yang harus diikuti.

Namun, perwujudan nilai moral itu patut dipertanyakan saat diwakilkan kepada tokoh Salma yang dikategorikan sebagai anak kecil, meski usianya tidak disebutkan secara eksplisit. Kesadaran yang ditampilkan Salma tampak lebih relevan ditunjukkan oleh seorang remaja yang mulai dapat berpikir kritis. Untuk menyebut usia, Piagete, dalam teori perkembangan anaknya, secara spesifik menyebut bahwa mulai usia sebelas tahun, anak mulai dapat berpikir abstrak, termasuk berpikir kritis terhadap berbagai hal dalam kehidupannya. Tahapan ini yang disebut sebagai formal operasional dalam perkembangan intelektual anak (Piaget, 2002).

Penjabaran teoretis mengenai karakteristik anak serta perkembangan moral dan intelektualnya memunculkan kemungkinan lain yang diharapkan teks, yaitu karakter Salma itu sendiri, termasuk usia paling logis untuk direpresentasikan olehnya. Berdasarkan karakteristik perkembangan moral dan intelektual, Salma paling tepat berada pada usia sekitar sebelas tahun atau menjelang akhir pendidikan dasar.

Apabila dikaitkan dengan tandatanda pada subpoin sebelumnya, maka karakter Salma memunculkan dua kebingungan: (1) apakah Salma digambarkan terlalu "kecil" atau kanakkanak dalam ilustrasinya atau (2) Salma merepresentasikan anak yang terlalu kritis untuk seusianya. Meskipun demikian, persoalan tersebut berhubungan dengan estetika naratif yang berkaitan dengan proses kreatif pengarang atau produksi bacaan 
tersebut oleh penerbit. Permasalahan lebih mendasar lainnya adalah makna tersembunyi di balik moral tersebut.

Makna yang dimaksud dalam pembacaan semiotika Barthes perlu didudukkan dalam hubungan signifier dan signified kembali seperti pada penjelasan subpoin sebelumnya. Signifikansi pertama atau pemaknaan denotatif dari setiap tanda dalam STH terkait moral pada hakikatnya telah dijelaskan pada di awal, yaitu terkait kesadaran tokoh Salma terhadap hakhaknya sebagai anak dan perjuangannya sebagai bentuk kepedulian sosial. Moral tersebut tergambar melalui kutipan 3, 4, dan 5 yang telah dipaparkan sebelumnya.

Selanjutnya adalah pemaknaan konotatif terhadap moral tersebut. Pemaknaan tersebut paling tidak terkait dengan dua konteks, yaitu (1) hak-hak anak secara global dan (2) intensi pengarang yang mewujud sebagai ideologi orang dewasa.

Pertama, terkait hak-hak anak. Perjuangan Salma mewujudkan perpustakaan di kampungnya disambut baik oleh pihak pemerintah setempat. Hal itu ditunjukkan dengan respons cepat pemerintah setempat dan pengakuan atas kerja keras Salma yang disebut "paham hak-haknya". Hak-hak yang dimaksud adalah hak mendapatkan bacaan di perpustakaan, memperoleh fasilitas untuk memenuhi hobinya, mendapatkan pendidikan, dan hak kesetaraan dalam perlakuan sosial, termasuk untuk anak difabel.

Hak-hak anak sebagaimana disebutkan merujuk pada hak-hak anak secara global. Hak-hak tersebut tertulis dalam Konvensi Hak-hak Anak Persatuan Bangsa-Bangsa (PBB) yang disahkan pada 1988. Dalam konvensi tersebut disepakati bahwa anak-anak di seluruh dunia harus memperoleh hakhaknya sesuai dengan yang telah diatur dalam kovensi tersebut. Terdapat 54 pasal dalam konvensi tersebut. Pasal 1 sampai dengan 42 mengatur hak-hak anak secara spesifik. Adapun pasal 43 hingga akhir mengatur kerja sama yang dilakukan oleh orang dewasa untuk mewujudkan hak-hak tersebut (Unicef, n.d.).

Perjuangan Salma yang disebut Ustadzah Salma sebagai "paham hak-hak anak" adalah perwujudan salah satu pasal dalam konvensi hak-hak anak PBB tersebut. Secara spesifik, pasal-pasal yang berhubungan dengan perjuangan Salma adalah pasal 12 yang berbunyi sebagai berikut:

Tiap anak berhak mengemukakan pendapat dan didengar dan dipertimbangkan pendapatnya saat pengambilan suatu keputusan yang akan mempengaruhi kehidupannya atau kehidupan anak lain (Pasal 12, Konvensi Hak-hak Anak PBB).

Dalam pasal tersebut disebutkan bahwa anak berhak mengemukakan pendapatnya, termasuk dipertimbangkan pendapatnya dalam pengambilan keputusan. Hal tersebut yang ditampilkan dalam teks STH dengan menggambarkan Salma sebagai anak yang berinisiatif baik mengirimkan surat kepada pemerintah untuk mendirikan perpustakaan di kampungnya. Permintaannya pun dikabulkan dan akhirnya pemerintah mengirimkan mobil perpustakaan sementara sebelum didirikan perpustakaan permanen.

Selain pendirian perpustakaan, pasal lain dalam Konvensi Hak-hak Anak PBB yang berkaitan dengan perjuangan Salma adalah pasal 23 sebagai berikut:

Setiap anak dengan disabilitas berhak atas pendidikan, pelatihan dan perlindungan khusus agar 
dapat menjalani kehidupan secara penuh (Pasal 23, Konvensi Hak-hak Anak PBB).

Pada pasal tersebut disebutkan bahwa anak-anak difabel harus memperoleh hak yang sama dengan anak lainnya dalam hal pendidikan, pelatihan, dan perlindungan. Hal tersebut juga tampak sebagai pesan yang ditunjukkan teks STH dengan menampilkan narasi anak difabel yang gembira atas kehadiran perpustakaan di kampungnya. Dengan demikian, teks STH melalui tokoh Salma berhasil menyuarakan hakhak anak sebagaimana telah disebut.

Dalam pembacaan Semiotika Barthes, Konvensi Hak-hak Anak PBB dijadikan acuan atau signified dari moral yang ditampilkan teks STH sebagaimana telah dipaparkan sebelumnya. Sebagai bagian dari sign 1 atau signifikansi tahap pertama, moral tersebut menjadikan Konvensi Hak-hak Anak PBB sebagai signified 2. Hubungan antara moral dalam STH dan Konvensi Hak-hak Anak PBB adalah signifikansi tahap kedua. Dengan kata lain, mitos dalam teks STH ini adalah sosialisasi Konvensi Hak-hak Anak PBB sebagai panduan hak-hak anak secara global.

Jika ditampilkan dalam bagan Semiotika Barthes, pembacaan ini dapat dilihat sebagai berikut:

\begin{tabular}{|c|c|c|}
\hline $\begin{array}{l}\text { Narasi tentang } \\
\text { moral yang } \\
\text { ditampilkan teks } \\
\text { STH } \\
\text { (Kutipan } 3,4,5 \text {, } \\
\text { dsb.) }\end{array}$ & $\begin{array}{c}\text { Kesadaran hak-hak } \\
\text { anak dan } \\
\text { kepedulian kepada } \\
\text { sesama }\end{array}$ & \\
\hline Signifier & Signified & \\
\hline \multicolumn{2}{|c|}{ Denotative Sign } & \\
\hline \multicolumn{2}{|c|}{ Moral dalam STH terkait Hak-hak Anak } & Sosialisasi Konvensi Anak-anak PBB \\
\hline \multicolumn{2}{|c|}{ Signifier 2} & Signified 2 \\
\hline \multicolumn{3}{|c|}{ Connotative Sign } \\
\hline
\end{tabular}

Bagan 3. Makna Denotatif dan Konotatif Teks STH
Kedua, terkait intensi pengarang yang mewujud dalam bentuk ideologi. Konsep ideologi paling sederhana terkait sastra dijabarkan Eagleton dalam Ideology. Ada banyak terminologi terkait ideologi yang tidak bisa didefinisikan mutlak, tetapi ada beberapa daftar yang disebutkan Eagleton sebagai ideologi. Di antaranya adalah ideologi sebagai proses produksi makna, tanda, dan nilai dalam kehidupan sosial dan bentuk-bentuk pikiran yang dimotivasi oleh ketertarikan sosial (Eagleton, 1991, hal. 1).

Mengacu pada terminologi tersebut, ideologi pada teks STH merupakan intensi pengarang untuk menyuarakan pesan-pesan di balik moral yang telah diketahui dalam signifikansi pertama. Sebagaimana telah disebutkan bahwa teks STH menampilkan moral berupa kesadaran hak-hak anak dan perlunya kepedulian sosial, ada makna lain yang harus disingkap melalui signifikansi kedua, yaitu menghubungkan moral tersebut dengan signified 2 yang berkaitan dengan konteks ideologi pengarang, yaitu bentuk-bentuk pikiran pengarang berdasarkan ketertarikan sosialnya.

Sebagai bacaan anak, teks STH harus menunjukkan bahwa unsur didaktik di dalamnya relevan dengan pembaca anak. Namun demikian, unsur didaktik tersebut sebagai perwujudan ideologi pengarang perlu ditampilkan dalam sudut pandang anak sehingga bacaan tersebut berhasil menjadi media penyampai moral yang efektif. Dalam kaitannya dengan moral teks STH, yaitu kesadaran hak-hak anak dan kepedulian sosial, tampak bahwa pengarang memiliki intensi lain 
yang bisa dilihat dengan signifikansi tahap kedua.

Jika dikaitkan dengan ideologi pengarang, moral dalam STH sebagai sign 1 dapat dikaitkan dengan keberadaan tanda-tanda lain yang muncul dalam teks, seperti: penyebutan tokoh Mama Suzanne dan mitos sosialisasi konvensi hak-hak anak PBB sebagaimana telah disebutkan berbunyi, "Tiap anak berhak tahu mengenai haknya. Orang dewasa juga perlu mengetahui hak-hak ini dan membantu anak memahaminya." Oleh karena itu, teks STH mengambil andil sebagai suara orang dewasa yang membantu anak memahami hak-haknya.

Jika ditampilkan dalam bagan Semiotika Barthes, proses signifikansi ini dilihat sebagai berikut.

sebelumnya. Tokoh

Mama Suzanne

berkaitan dengan

Suzanne Mubarak, istri Presiden Mesir periode

1981

sampai dengan

2011. Suzanne dikenal sebagai tokoh yang peduli akan hak-hak anak, bahkan mendirikan

\begin{tabular}{|c|c|c|c|}
\hline $\begin{array}{l}\text { Narasi tentang } \\
\text { moral yang } \\
\text { ditampilkan teks } \\
\text { STH }\end{array}$ & $\begin{array}{c}\text { Kesadaran } \\
\text { hak-hak anak } \\
\text { dan kepedulian } \\
\text { kepada sesama }\end{array}$ & & \\
\hline \multirow{2}{*}{\multicolumn{3}{|c|}{ Dennotative Sign }} & \\
\hline & & & \\
\hline \multicolumn{2}{|c|}{$\begin{array}{l}\text { Moral dalam STH terkait Hak-hak } \\
\text { Anak }\end{array}$} & $\begin{array}{l}\text { Sosialisasi Konvensi } \\
\text { Anak-anak PBB }\end{array}$ & \\
\hline \multirow{2}{*}{\multicolumn{3}{|c|}{\begin{tabular}{c|c} 
Signifier 2 & Signified 2 \\
Connotative Sign 1 \\
\end{tabular}}} & \\
\hline & & & \\
\hline \multicolumn{3}{|c|}{ Teks STH sebagai Sosialisasi Konvensi Anak-anak PBB } & $\begin{array}{l}\text { Kampanye Hak-hak Anak } \\
\text { oleh Suzanne Mubarak }\end{array}$ \\
\hline \multicolumn{3}{|c|}{ Signifier 3} & Signified 3 \\
\hline \multicolumn{4}{|c|}{ Connotative Sign 2} \\
\hline
\end{tabular}

Museum Anak Kairo di Mesir pada 1986.

Bagan 4. Makna Konotatif dan Denotatif Teks STH

Berkaitan dengan biografi Suzanne tersebut, moral dalam teks STH berkaitan dengan Suzanne yang pada saat teks STH diterbitkan (2006) masih menjabat sebagai ibu negara serta aktivis hak-hak anak. Oleh karena itu, teks hadir sebagai upaya untuk menyuarakan hak-hak anak, termasuk biografi Suzzanne sebagai tokoh yang berpengaruh di Mesir, termasuk dalam aktivisme hak-hak anak. Oleh karena itu, sosialisasi konvensi hak-hak anak sebagai mitos atau makna konotatif yang sudah dijelaskan sebelumnya merujuk pada signified baru (signified 3), yaitu teks hadir sebagai upaya mengampanyekan hak-hak anak dan biografi Suzanne Mubarak yang berkaitan erat dengan hal tersebut.

Kampanye terhadap kovensi hakhak anak adalah bagian dari upaya sosialisasi hak anak kepada masyarakat. Hal tersebut juga merupakan bagian dari konvensi itu sendiri, yaitu pasal 42 yang
Bagan tersebut menunjukkan bahwa proses signifikansi yang berlangsung dalam teks STH mencapai paling tidak hingga tiga tahap dan dapat terus terjadi. Pembacaan semiotika hingga tahap ketiga ini menunjukkan bahwa teks STH hadir sebagai bagian dari kampanye hak-hak anak sesuai dengan Konvensi Hak-hak Anak PBB oleh Suzanne Mubarak yang pada saat teks diterbitkan (2006) merupakan ibu negara segara aktivis hak-hak anak.

\section{KESIMPULAN}

Teks STH (2016) adalah novel grafis Mesir yang ditulis Fatimah al-Madul, penulis bacaan anak. Sebagai bacaan anak, teks STH sesuai dengan karakteristik sastra anak, yaitu bernilai didaktik dan dikemas dalam tampilan yang menarik, yaitu dilengkap ilustrasi sehingga dapat disebut sebagai novel grafis. Moral dalam teks yaitu 
pentingnya kesadaran akan hak-hak anak dan kepedulian sosial. Hal tersebut ditampilkan teks melalui tokoh anak bernama Salma yang berjuang menghadirkan perpustakaan di kampungnya dengan menyurati pemerintah setempat.

Dengan pembacaan semiotika Barthes, moral tersebut adalah bagian dari pemaknaan atau signifikansi tahap pertama. Setelah itu, moral dalam teks STH terkait hak-hak anak adalah bagian dari sosialisasi Konvensi Hak-hak Anak PBB yang terdiri atas 54 hak anak yang beberapa di antaranya diwujudkan dalam narasi teks STH, yaitu tentang hak akan pendidikan dan kesetaraan perlakuan sosial bagi difabel. Dengan demikian, sosialisasi ini merupakan makna konotatif pertama yang ditunjukkan oleh teks STH.

Namun demikian, signifikansi teks STH terus berlanjut dengan membaca beragam tanda lain yang muncul terkait dengan makna konotatif pertama. Signifikansi selanjutnya memunculkan makna konotatif kedua, yaitu sosialisasi Konvensi Hak-hak Anak PBB sebagai bagian dari upaya teks STH mengampanyekan hak-hak anak yang melibatkan Suzanne Mubarak sebagai ibu negara dan aktivis hak-hak anak pada saat teks STH diterbitkan (2016). Makna konotatif atau mitos tersebut adalah perwujudan dari ideologi pengarang sebagai orang dewasa dalam teks bacaan anak yang ditulisnya.

\section{DAFTAR PUSTAKA}

Al-Ma'dul, F. (2006). Salma Ta'rifu Huquuqahaa. Nahdhat Mishr. Ashour, R. (2008). Arab Women Writers: A Critical Reference Guide 1873-
1999. The American University in Cairo Press.

Barthes, R. (1972). Mythologies. The Noonday Press.

Beatens, J. (2001). The Graphic Novel (J. Beatens (ed.)). Leuven University Press.

Eagleton, T. (1991). Ideology. Verso.

Garz, D. (2009). Lawrence Kohlberg: An Introduction. Barbara Budrich.

Hunt, P. (2002). Understanding Children's Literature. Routledge.

Krippendorf, K. (2004). Content Analysis an Introduction to Its Methodology. Sage Publications.

Kurniawan, H. (2009). Sastra Anak dalam Kajian Strukturalisme, Sosiologi, Semiotika, hingga Penulisan Kreatif. Graha Ilmu.

Nurgiyantoro, B. (2005). Sastra Anak Pengantar Pemahaman Dunia Anak. UGM Press.

Nursugiharti, T. (2020). Ideologi Sastra Anak Habib Sang Pendekar Bumi Melayu. Jurnal LOA Jurnal Ketatabahasaan dan Kesastraan, 15 no. 1 ,

Piaget, J. (2002). The Construction of Reality. Routledge.

Stephens, \& McCallum. (2011). Ideology and Children's Books. In Handbook of Research on Children's and Young Adult Literature. Routledge.

Unicef. (n.d.). konvensi-hak-anak-versianak-anak. Unicef. Diambil 18 Oktober 2020, dari https://www.unicef.org/indonesia /id/konvensi-hak-anak-versi-anakanak

Weber, R. P. (1990). Basic Content Analysis. Sage Publications. 